\title{
Determinants of public employment services: exploring the relationship between benefit conditionality and partisan politics
}

\author{
Daniel Fredriksson (D) \\ Swedish Institute for Social Research, Stockholm University, Stockholm 10691, Sweden \\ Email: daniel.fredriksson@sofi.su.se
}

(Received 1 December 2019; revised 21 October 2020; accepted 13 November 2020)

\begin{abstract}
The purpose of this study is to analyse determinants of resources devoted to public employment services (PES). It has proven difficult to disentangle 'carrots' (placement and services) from 'sticks' (sanctions and monitoring) when tracking the development of PES spending. This has contributed to ambivalence concerning the role of partisan politics, especially since welfare states have been argued to increasingly emphasize the 'sticks' aspect of the PES, irrespective of ideological orientation. This suggests that the role of partisan politics should be analysed together with 'demanding' activation, which is made possible with novel data on unemployment benefit conditionality. The analysis includes 16 welfare states and results indicate that left and secular centre-right parties are associated with increased resources devoted to PES, but that effects of partisan politics are contingent on the form and extent of benefit conditionality. Increased conditionality is associated with higher PES spending, thus nuancing the cost-containment argument for activation.
\end{abstract}

Keywords: Public employment services; activation; active labour market policy; comparative analysis; partisan politics

\section{Introduction}

Public employment services (PES) is a core type of active labour market policy (ALMP). The PES facilitate job matching processes and is arguably a nexus in most labour market policy systems due to its role as implementer of other types of ALMPs (King \& Rothstein, 1993; Mosley, Keller, \& Speckesser, 1998; Rothstein, 1985). Since the PES have important mediating effects on other types of programmes, it may be considered essential for well-functioning labour market policy. However, the activitities of the PES are multidimensional. The PES provide services to the unemployed in form of advice and allocation into other labour market programmes, but also have coercive elements as the PES often are responsible for monitoring unemployment benefit claimants and imposing sanctions in cases of non-compliance. This duality between support and coercion has important implications, especially when considering analysis of the driving forces behind policy change and the resources devoted to PES.

In terms of partisan politics, interventions that have straightforward redistributive consequences, eg., training programmes that enhance human capital and employment chances among participants, lend themselves more easily to theorize through the lens of political preferences (Nelson, 2013). However, it has proven difficult to disentangle 'carrots' (services) from 'sticks' (sanctions and monitoring) when tracking the development of resources devoted to PES. Hypotheses related to partisan politics are therefore ambivalent and most studies that analyse political determinants of more fine-grained categories of ALMP omit PES altogether, or refrain from theorizing partisan effects on PES spending 
(eg. Cronert, 2019; Nelson, 2013; Vlandas, 2013). Concurrently, the literature on activation and the so-called 'activation turn' have argued that labour market policy is converging. In relation to PES, countries have been argued to-irrespective of ideological orientation-alter the orientations of the PES to emphasize the 'sticks' of activation, ie., increased monitoring of benefit claimants and job-seekers rather than providing the service of finding the best job match or intervention (Eichhorst \& Konle-Seidl, 2008; Moreira \& Lødemel, 2014; Weishaupt, 2010). Unemployment benefits have been subject for similar and related 'demanding' reforms, with stricter benefit eligibility criteria and job-search requirements (Clasen \& Clegg, 2007; Knotz, 2018; Nelson, 2013; Weishaupt, 2011). While the development towards activation partly relates to changes in how the deservingness of the unemployed are perceived (eg. Clasen \& Clegg, 2003; Schumacher, Vis, \& Van Kersbergen, 2013; Van Oorschot, 2000), a key rationale behind stricter conditionality and sanctions of benefits have been to reduce costs of social protection in face of austerity (Bengtsson, de la Porte, \& Jacobsson, 2017; Huber \& Stephens, 2001; Knotz, 2019). While some studies indicate that monitoring can be a cost-effective option (Boone et al., 2007; Raffass, 2017), others argue that expanding systems of monitoring and sanctions can be associated with substantial costs (Eichhorst \& Konle-Seidl, 2008, p. 427; Watts \& Fitzpatrick, 2018, p. 9). Although recent comparative studies show that partisan politics seems to be unrelated to the development of 'demanding' activation as such (Knotz, 2019), whether increased conditionality contributes to reduced or increased expenditures on PES is still unclear. If the development towards more 'demanding' activation take precedence over political preferences, it also suggests that in order to better understand the role of partisan politics, the analysis of resources devoted to PES should incorporate activation as well.

The purpose of this study is hence to explore determinants of PES spending, focussing particularly on partisan politics and activation. Based on the discussion above, two questions can be posed. First, is partisan politics related to resources devoted to PES once we account for the increase of 'demanding' activation in many countries? Second, the increase of activation as such associated with spending on PES? In terms of partisan politics, I distinguish between left, secular centre-right and confessional parties, where the latter refer, mostly, to the European Christian democratic parties that in important respects differ from secular centre-right parties in, eg., preferences for labour market intervention (eg. Kalyvas \& Van Kersbergen, 2010; Korpi \& Palme, 2003; Nelson, 2013). In effort to disentangle services from sanctions in the activities of the PES, I utilize new data on sanctions and conditions in unemployment insurance (Knotz \& Nelson, 2018), thus enabling analysis of 'demanding' activation as well as partisan politics. The study analyses the period 1985-2011 and includes 16 OECD countries; Australia, Austria, Belgium, Canada, Denmark, Finland, France, Germany (West Germany before 1991), Ireland, Japan, the Netherlands, New Zealand, Norway, Sweden, Switzerland and the United Kingdom. The first section provides a discussion of the PES and potential links between partisan politics, activating policies and PES spending. Data and methodological considerations are then discussed, focusing particularly on the time-series methodology of error correction models. The penultimate section presents the empirical results, which is followed by a concluding discussion.

\section{Public employment services expenditure}

The PES consists of a heterogeneous set of policies. Broadly speaking, five components or responsibilities can be distinguished: Job brokerage to facilitate matches between supply and demand; provision of labour market information to employers and job-seekers by collecting data on job vacancies and potential applicants; allocation and implementation of ALMP; administration of unemployment benefits; and management and coordination of labour migration (OECD/IDB/WAPES, 2016). While theorizing effects related to partisan politics or 'activation' may be considered fairly straightforward for each separate component, a consistent problem for country-comparative studies is that the resources devoted to PES have historically not been available with respect to separate areas of responsibility, but only in terms of total resources. The pitfalls of analysing total government spending has been noted in relation to ALMP and social policy more generally (Clasen, Clegg, \& Goerne, 2016; Siegel, 2007), but can 
be considered even more problematic in relation to PES. Even though increased resources to the PES are argued to be 'open-ended', ie., more resources equalling more impact on unemployment (Thuy, Hansen, \& Price, 2001, p. 29), it is difficult to determine what high or low spending on PES means in terms of 'sticks' and 'carrots'. This inherent ambiguity is the prime reason for refraining from partisan hypotheses (Nelson, 2013; Vlandas, 2013), but also plays a role in relation to activation, as it is difficult to determine if the observed increase in 'demanding' activation is related to costs for the key institution that implements activation policies, ie., the PES. The following sections will delineate some provisional expectations concerning the potential relationships that activation and partisan politics may have to PES resources.

\section{Activation and benefit conditionality}

The turn to activation has been a pervasive topic in the social policy research of recent decades. Although it is important to note that activation may be 'enabling' when considering expansion of ALMPs such as training schemes or the placement services and job-search assistance of the PES, a great deal of research has focused on the increase of 'sticks' or 'demanding' aspects of activation and the consequences of this development for unemployed and other marginalized groups. In this regard, many countries have come to emphasize 'workfare' or 'making work pay', ie., pushing unemployed or social assistance beneficiaries to take the first available job (Lødemel, 2004; Moreira \& Lødemel, 2014; Rueda, 2015; Van Oorschot, 2004). While increases in 'demanding' activation can be traced in many areas of social protection (Clasen \& Clegg, 2006, 2011), this study focusses on two aspects of benefit conditionality related to unemployment insurance benefits (Knotz, 2018).

A key justification for 'demanding' activation is cost-containment. With respect to unemployment insurance, countries thus impose stricter conditions to receive benefits, and stricter sanctions, ie., reduced or rescinded benefits, when the unemployed fails to comply to, eg., job-search requirements, in effort to reduce costs during periods of high unemployment (Bengtsson, de la Porte, \& Jacobsson, 2017; Huber \& Stephens, 2001; Knotz, 2019; Rueda, 2015).

Since fewer individuals are eligible and receiving benefits, it is reasonable to argue that stricter conditions and sanctions may reduce spending on unemployment insurance. However, stricter conditionality may have varying effects on spending associated with different ALMPs. Some studies argue that monitoring benefit claimants and imposing sanctions for non-compliance can be a cost-effective alternative compared to expanding more expensive forms of ALMP, eg., training programmes (Boone et al., 2007; Raffass, 2017). However, for the PES, which are responsible for benefit administration, expanding systems of monitoring can be associated with substantial costs, both with respect to building and maintaining administrative systems and with respect to staff timemanagement, especially in cases where monitoring is added on top of existing tasks (Eichhorst \& Konle-Seidl, 2008, p. 427; Watts \& Fitzpatrick, 2018, pp. 104-107). In terms of restricting access to benefits, ie., changing conditions or eligibility criteria, the logic is similar. Restricting access may reduce spending on passive benefits and categories of 'enabling' ALMPs, but it is likely that curbing benefit rights is associated with increased costs for the PES, since systems of assessing the individual right to benefit may be associated with considerable costs in a similar way to that of systems of monitoring and sanctions.

\section{Partisan politics and labour market policy}

The role of partisan politics for the development of labour market policy is often reduced to the proclivity of using government intervention along the left-right continuum. Expansive ALMPs are hence typically denoted 'leftist', whereas the approach of deregulation and reliance on the market is signified as 'rightist' (Nelson, 2013). As recent studies have shown, this is an oversimplification of political preferences that are more nuanced when considering the wider range of ALMP (Nelson, 2013; Vlandas, 2013). The oversimplification is arguably particularly misleading in relation to the PES, where either 'sticks' or 
'carrots' can be more salient. Since analysis of the relationship between partisan politics and expansion or retrenchment of ALMP seldom goes beyond the left-right scale, preferences for government intervention in the labour market among other political parties tend to be overlooked. ${ }^{1}$

Confessional parties have, eg., been shown to pursue egalitarian social policies in competition with left parties during welfare state expansion, and to take intermediate positions between left and secular centrist-right parties in cutting back major social insurance programmes during the era of retrenchment (Huber \& Stephens, 2001; Korpi \& Palme, 2003; Montanari \& Nelson, 2013; Van Kersbergen, 1995). With respect to labour market policy, however, confessional parties do not seem to support comprehensive strategies or programmes (Hicks \& Kenworthy, 1998; Huber \& Stephens, 2001, pp. 185-186; Van Kersbergen, 2009, p. 135; Van Kersbergen \& Hemerijck, 2009). The lack of support for labour market policies emanates from several sources, but may be traced explicitly to principles of subsidiarity. Confessional parties thus have a wariness for government interventions, but not necessarily from a laissez-faire view of the labour market. Rather, confessional parties tend to view employment policy as a responsibility of the social partners, not the government (Klitgaard, Schumacher, \& Soentken, 2015; Van Kersbergen, 1995, pp. 174-191) and confessional parties consistently downplay active policies, instead utilizing, eg., labour-shedding/early retirement to reduce unemployment (eg., Esping-Andersen, 1996), and focus on the provision of cash benefits rather than provision of services towards the unemployed (Huber \& Stephens, 2001). The discussion thus indicates that confessional parties are less likely to be associated with higher levels of PES spending.

In a similar vein, left parties are often associated with social investment and market interventions that reduce unemployment, making left parties likely to spend considerable resources on ALMP (Boix, 1998; Huo, Nelson, \& Stephens, 2008; Nikolai, 2012; van Vliet \& Koster, 2011). However, some scholars have argued that left parties are less inclined to support ALMPs (Rueda, 2006, 2007; Tepe \& Vanhuysse, 2013; Vlandas, 2013). This counter-argument is based on the theory of insider-outsider cleavages, where left parties favour insiders of labour markets rather than promoting policies for outsiders, ie. the unemployed and those outside the labour force. While the latter stance may be an indication that political preferences are less clear-cut in relation to PES, it should be noted the majority of studies tend to indicate that left parties support active policies (see Nelson, 2013). Others have shown that the insider-outsider cleavages have contradictory impacts on the preferences of left parties that are contingent on institutional contexts (Fossati, 2018a). There is also reason to believe that left parties devote resources to PES in light of the long history of ALMP as a distinctly social democratic policy strategy. For instance, in the Nordic welfare states, the organization and execution of ALMP hinged, to a large degree, on well-functioning PES (King \& Rothstein, 1993; Rothstein, 1985; Weishaupt, 2011). Arguably, the prime function of PES as a way of reducing unemployment through services and allocation of unemployed into other labour market programmes indicate that left parties can be expected to be associated with higher PES spending. This assumption is bolstered by the fact that left parties are more likely to be punished electorally by high unemployment levels and economic crises, which creates incentives to pursue policies aiming to reduce unemployment (Lindvall, 2014; Powell \& Whitten, 1993).

Secular centrist-right parties, lastly, are usually thought to be cautious of using labour market interventions and instead trust the market to counter unemployment. As such, centrist-right parties are generally assumed to block ALMPs. Instead, the focus is on creating work-incentives by lowering unemployment benefit levels and deregulating labour markets to achieve more flexibility (Bonoli, 2010; Bradley \& Stephens, 2007; Furåker, 1997; Nelson, 2013). This argument, however, neglects that PES is a type of labour market policy that facilitates labour market processes, where the PES, eg., help employers to post vacancies as well as providing support for applicants to fill these vacancies. As stressed above, PES can also be combined with strong work incentives, which is often the case in countries where centre-right

\footnotetext{
${ }^{1}$ It should be acknowledged that the political landscape has changed dramatically during the last decades with the emergence of green and populist parties. The literature concerning how these 'new' parties will influence welfare state development has yet to develop fully. Since their scope of influence can be assumed to be limited with respect to the period and countries in this study, they are not analysed separately.
} 
parties dominates (Bonoli, 2010). Hence, while centre-right parties often promote market solutions (Klitgaard, Schumacher, \& Soentken, 2015), there is a reason to believe that centrist-right parties could support the 'enabling' aspects of the PES, especially in combination with 'demanding' activation.

\section{The relationship between partisan politics and benefit conditionality}

The discussions above argue that 'demanding' activation may increase PES spending, and that political parties have different preferences in relation to the 'enabling' part of the PES, where left and secular centre-right parties are likely to spend more on PES compared to confessional parties. Since partisan politics and 'demanding' activation have yet to be analysed simultanously, it is difficult to predict the more salient factor in relation to the development of the PES. However, while the convergence of benefit conditionality across countries has mostly been attributed to declining economic conditions (Knotz, 2019), there is also a reason to believe that the relationship that partisanship may have to PES is conditional on the particular forms and extent of activation policies in a given country. This has partly been explored in relation to voters' preferences, where voters in more 'enabling' countries, eg., Denmark, are less supportive of stricter activation policies (Fossati, 2018b).

In this regard, preferences among political parties with respect to unemployment insurance is relevant to consider. Left parties are, eg., typically associated with generous unemployment insurance (Huo, Nelson, \& Stephens, 2008; Scruggs \& Allan, 2004). However, to be able to retain generous benefits and promote employment during periods when costs of social protection must be constrained, left parties may focus on increasing PES spending particularly in contexts where benefit sanctions are strict. Individuals thus receive generous benefits and support through the PES, but are subject to stricter sanctions when failing to comply to regulations. Secular-centrist right parties are also likely to promote the enabling aspects of PES, but may do so under different circumstances. Since secular-centrist right have traditionally not been interested in extending rights or generosity of unemployment benefits (Scruggs \& Allan, 2004), they may spend more on PES in contexts where conditions to receive benefits are stricter. That is, when work-incentives are high due to curbed access, centre-right parties promote the enabling aspects of the PES rather than sanctioning those already unemployed. Thus, the resources that political parties devote to PES are contingent on the forms and extent of 'demanding activation'.

\section{Data}

The dependent variable in this study is public employment services expenditure, which is publicly available from 1985 in the OECD Social Expenditure database (OECD, 2015b). The exact content included in expenditure varies somewhat between countries, but typically includes placement, counselling and vocational guidance. In addition, administration costs of labour market agencies as well as other labour market programmes may be included. From 1998, the spending measure is further divided in benefit administration and placement services, which would be preferred as it more closely conform to 'enabling' and 'demanding' aspects of the PES, but is not utilized since the number of years with more detailed data is lower than recommended in time-series analysis.

There are various ways of measuring spending, where some studies, eg., use the total spending as a percentage of GDP. In this study, expenditure on PES is defined as spending in U.S. dollar purchasing power parities (PPP) per unemployed, which take effort or 'intensity' into account (Bassanini \& Duval, 2006; van Vliet \& Koster, 2011). As a sensitivity test, the models below have been estimated with PES spending as a percentage of GDP, which is discussed further below.

The strength of political partisanship is measured as party shares of cabinets collected from the Political Data Yearbook (European Journal of Political Research, 2014) and extends data on political partisanship from Korpi and Palme (2003). Cabinet shares have been calculated as the number of ministerial portfolios held by left parties, confessional parties and secular centrist-right parties, respectively, divided by the total cabinet size and weighted for cabinet changes during each observation 
year. ${ }^{2}$ In the few instances that green or right-wing populist parties have had cabinet seats, they have been categorized as secular centrist-right parties since their scope of influence can be assumed limited with respect to the period and countries in this study. Although cabinet share is the most common measure of partisanship, some studies have used parliamentary share instead (eg. Bonoli, 2013). Using parliamentary shares might capture long-term ideological shifts, but the focus on policy change makes the use of cabinet shares more reasonable. Longevity or cumulative incumbency of parties has also been suggested, but is arguably more relevant when analysing welfare state programmes with long maturation periods, such as pension schemes (Huber \& Stephens, 2014).

Data regarding benefit conditionality is collected from 'The Comparative Conditions and Sanctions Dataset' (Knotz \& Nelson, 2018). Two composite measures are available: Strictness of sanctions and strictness of benefit conditions. These are calculated as the summed scores of several component indicators, eg., job-search requirements in relation to conditions, and consequences of the first refusal of an offer of employment in relation to sanctions. The summed scores have then been divided by the theoretical maximum to reach an overall score varying between 0 (very lenient) and 1 (very strict). More detailed information regarding the construction of the indicators is available in $\operatorname{Knotz}(2018,2019)$.

In addition to partisan politics and benefit conditionality, there are numerous structural factors that have been suggested to be relevant for labour market policy development. Among them are unemployment, deindustrialization, budget deficits, economic growth, macro-corporatism and employment protection legislation (eg. Huo, Nelson, \& Stephens, 2008; Nelson, 2013; Vlandas, 2013). Of these, unemployment stands out as a key factor as it constitutes the raison d'être for labour market policy. For unemployment, civilian unemployment rates are used. Deindustrialization is measured as the share of the labour force active in the service sector. Data on coordination or macro-corporatism is from Visser (2013) and measured by centralization of wage bargaining along a five-point scale. The annually adjusted budget deficit is measured as percentage of GDP. In addition to these, GDP per capita (in log form) is also included as a control variable. Except for cabinet composition, conditionality and wage coordination, all independent variables are from the OECD Main Economic Indicators and Social Expenditure databases (OECD, 2015a, 2015b).

\section{Methods}

This study uses error correction models (ECM) to analyse how various determinants are related to PES spending. Dynamic regression models, like ECM, builds on the idea that there are both short-term effects and long-term associations between different time-series. Sudden shocks to the system can be felt immediately, but are also absorbed over time with a more or less steady return to equilibrium. An advantage of ECMs is the opportunity to specify a dynamic model where short- and long-term effects, defined in differences and levels respectively, are separated and estimated simultaneously. Such dynamics are increasingly being analysed in studies of welfare state development, and are theoretically appealing since determinants may influence spending both immediately and over the long-term. A general bivariate ECM model can be written as:

$$
\Delta Y_{i t}=\alpha+\beta_{0} Y_{i t-1}+\beta_{1} \Delta X_{i t}+\beta_{2} X_{i t-1}+\varepsilon_{i t}(1)
$$

In Equation (1), the estimated coefficient of the lagged level of $Y$, or $\beta_{0}$, is the error correction coefficient. If there is an error correcting mechanism, $\beta_{0}$ should be negative and statistically significant (De Boef \& Keele, 2008). $\beta_{1}$ captures immediate or short-term effects of $X_{i}$ at time $t$, while $\beta_{2}$ captures the

\footnotetext{
${ }^{2}$ It has recently been argued that the unit of analysis should be cabinet-years rather than country-years, since cabinet composition does not change annually and produce overconfident standard errors (Garritzmann \& Seng, 2020). The suggested solution is a multilevel approach, where variables with different time intervals can be estimated simultaneously. While an important development, the present study retains the country-year approach, since convergence issues precluded multilevel modelling.
} 
effects on $Y_{i}$ of a one-unit increase in $X_{i}$. This term is lagged 1 year, which lessens problems of reverse causality, which could otherwise be a problematic issue, especially when including labour market policies and unemployment in the same model (Bassanini \& Duval, 2009). If there is reason to believe that variables should be lagged with more than 1 year, eg. due to cyclically recurring events, the number of lags can be determined using the Bayesian information criterion (BIC). Doing so indicated 1-year lags to be appropriate for most variables. There were some indications that the lag should be 2 years for unemployment, but the main results are unaffected regardless of lag choice. The average lags are available in the Appendix Table A1.

The specified model also provides a straightforward way to calculate the total long-term effect of a one-unit increase in $X_{i}$, which in most instances is more interesting when a long-term relationship is present. This effect is commonly called the 'long-run multiplier' (LRM), since it depends on the size of the error correction coefficient. In ECM, the LRM is equal to $-\left(\beta_{2} / \beta_{0}\right)$. It is thus the total effect of a oneunit increase in $X_{i}$, distributed beyond $t+1$, at the rate determined by the error correction coefficient.

An advantage of the ECM approach is that it reduces many of the problems otherwise common in time-series analysis. However, some issues are still important to take into consideration. In the ECM framework, all the included time-series have to be either stationary or non-stationary (De Boef \& Keele, 2008; Keele, Linn, \& Webb, 2016), which is determined using unit-root tests. These are available in the Appendix Table A2. Modified Wald tests and Pesaran's test for cross-sectional independence, respectively, indicate that panels are both dependent and correlated. Standard errors that correct for both heteroscedasticity and contemporaneous correlation, as suggested by Beck and Katz (1995), are therefore used. Wooldridge tests for autocorrelation in panel data indicates autocorrelation for all time-series when these are expressed in levels, but not when expressed in differences (see Drukker, 2003). I apply panel-specific autocorrelation since the remaining variables are estimated both in terms of change and levels. Finally, multicollinearity can produce spurious results if the independent variables of interest are highly correlated. However, collinearity diagnostics indicated no multicollinearity with respect to partisan politics and the two measures of activation.

\section{Empirical analysis}

\section{Descriptive statistics}

Table 1 shows descriptive statistics for the main variables of interest and shows averages of PES spending, party representation in cabinets and the strictness of conditions and sanctions. PES expenditures have seen major fluctuations during the past three decades. In terms of average expenditure, a rise in the beginning of the 1990s was accentuated after the onset of the oft-cited 'activation turn', and then stabilized on a higher level (OECD, 2015b). As evident from the table, there is substantial variation across countries in terms of resources devoted to PES. The scope to detail each country is limited, but some notes should be made concerning outliers. Netherlands and Denmark, eg., clearly spend more than other countries. Since the 1990s, both countries have adopted a 'flexicurity' approach, which is a collection of policies that aim to promote work incentives (or flexibility) combined with high levels of social security and ALMP, of which PES is a part (Boeri, Conde-Ruiz, \& Galasso, 2012; Van Oorschot, 2004; Van Oorschot \& Abrahamson, 2003). This may, to some degree, explain the higher spending. As shown by Knotz (2018), the strictness of sanctions and conditions has increased substantially in many countries since the 1980s, well before the 'activation turn' in the late 1990s, which is often cited as the watershed for 'demanding' activation (Freeman, 2005; Nelson, 2013).

\section{Regression results}

We begin by doing a multivariate ECM on the determinants of total PES spending over the entire period from 1985 to 2011. The results of the regressions are presented in Table 2. The first model includes partisan politics, and the second model adds measures of 'demanding' activation. The underlying 
Table 1. Descriptive statistics.

\begin{tabular}{|c|c|c|c|c|c|c|}
\hline & \multirow{2}{*}{$\frac{\text { PES (PPP US\$ per unem) }}{\text { Total }}$} & \multicolumn{3}{|c|}{ Cabinet share } & \multicolumn{2}{|c|}{ Conditionality } \\
\hline & & Left & $\begin{array}{c}\text { Secular } \\
\text { centre-right }\end{array}$ & Confessional & Sanctions & Conditions \\
\hline Australia & 1.48 & 0.49 & 0.51 & 0.00 & 0.40 & 0.75 \\
\hline Austria & 1.98 & 0.48 & 0.11 & 0.41 & 0.36 & 0.42 \\
\hline Belgium & 1.29 & 0.36 & 0.30 & 0.33 & 0.61 & 0.45 \\
\hline Canada & 1.21 & 0.00 & 1.00 & 0.00 & 0.39 & 0.25 \\
\hline Denmark & 2.60 & 0.28 & 0.71 & 0.02 & 0.28 & 0.61 \\
\hline Finland & 0.98 & 0.33 & 0.67 & 0.01 & 0.44 & 0.54 \\
\hline France & 1.24 & 0.47 & 0.53 & 0.00 & 0.59 & 0.41 \\
\hline Germany & 1.77 & 0.31 & 0.20 & 0.49 & 0.53 & 0.50 \\
\hline Ireland & 1.23 & 0.11 & 0.72 & 0.17 & 0.49 & 0.31 \\
\hline Japan & 2.33 & 0.03 & 0.97 & 0.00 & 0.28 & 0.38 \\
\hline Netherlands & 5.63 & 0.23 & 0.37 & 0.40 & 0.71 & 0.53 \\
\hline New Zealand & 0.82 & 0.47 & 0.53 & 0.00 & 0.46 & 0.76 \\
\hline Norway & 1.90 & 0.58 & 0.32 & 0.10 & 0.50 & 0.63 \\
\hline Sweden & 2.41 & 0.68 & 0.29 & 0.03 & 0.35 & 0.46 \\
\hline Switzerland & 2.50 & 0.29 & 0.46 & 0.25 & 0.51 & 0.27 \\
\hline United Kingdom & 1.95 & 0.42 & 0.58 & 0.00 & 0.56 & 0.51 \\
\hline
\end{tabular}

Averages between 1985-2011.

Abbreviations: PES, public employment services; PPP, purchasing power parities.

assumption is that when we control for the two aspects of 'demanding' activation, what remains reflect the 'enabling' aspects of the PES. When comparing the estimates from the first two models, the need of incorporating conditionality when assessing the effects of partisan politics on PES spending seems to be confirmed. Partisan effects are revealed only when controlling for the strictness of sanctions and the strictness of conditions. When doing so, left and secular centre-right parties are associated with higher spending on PES compared to confessional parties, which are the reference category. Both differenced and lagged estimates show that when cabinet shares of left or centre-right parties increase, PES spending also increase. With respect to the strictness of sanctions and the strictness of conditions, respectively, only the lagged estimate for strictness of conditions seems to be associated with higher expenditure. These results hold when controlling for macro-economic and contextual factors in the last model. That partisan effects are revealed only when including 'demanding' activation indicates that the two are related even though, as discussed above, partisan politics has been shown to not be related to the increase of conditionality as such. I will return to this issue below.

Expressing the results from Table 2 in terms of temporal dynamics, there is evidence of long-term effects as several LRM are statistically significant. The LRMs show that partisanship and strictness of conditions have a long-term relationship with spending on PES, where increased cabinet shares for left and secular-centre right parties as well as increased strictness of conditions are associated with increased spending on PES over the long-term. For strictness of conditions the estimates are robust to the inclusion of macro-level controls, whereas long-term effects of partisanship are less stable, although statistically significant at the 10 per cent level. 
Table 2. Determinants of PES expenditure 1985-2011.

\begin{tabular}{|c|c|c|c|c|c|c|}
\hline & \multicolumn{2}{|c|}{ Model 1} & \multicolumn{2}{|c|}{ Model 2} & \multicolumn{2}{|c|}{ Model 3} \\
\hline & Change & Lag & Change & Lag & Change & Lag \\
\hline PES & & $-0.09^{*}$ & & $-0.17^{\star * *}$ & & $-0.23^{* * *}$ \\
\hline Left cabinet share & 0.53 & 0.62 & $0.59^{\star}$ & $0.75^{\star}$ & 0.51 & $0.60^{*}$ \\
\hline Centre-right cabinet share & 0.47 & 0.52 & $0.59^{*}$ & $0.67^{*}$ & $0.67^{\star}$ & $0.64^{*}$ \\
\hline Strictness of sanctions & & & -0.03 & 0.12 & 0.12 & -0.07 \\
\hline Strictness of conditions & & & 0.47 & $1.54^{\star \star *}$ & 0.64 & $1.65^{\star}$ \\
\hline Unemployment rate & & & & & $-0.17^{\star * *}$ & -0.03 \\
\hline Deindustrialization & & & & & 3.03 & 2.77 \\
\hline Wage coordination & & & & & $-0.15^{\star \star}$ & $-0.16^{*}$ \\
\hline GDP per capita (log) & & & & & 1.43 & 0.66 \\
\hline Adjusted deficit & & & & & -0.00 & $0.04^{*}$ \\
\hline Employment protection & & & & & -0.07 & $0.70^{*}$ \\
\hline Constant & -0.361 & & $-1.61^{\star * \star}$ & & $-2.49^{* *}$ & \\
\hline \multicolumn{7}{|l|}{ Long-term effects (LRM) } \\
\hline Left cabinet share & 6.92 & & $4.40^{*}$ & & $2.60+$ & \\
\hline Secular-centre cabinet share & 5.85 & & $3.92^{*}$ & & $2.80+$ & \\
\hline Strictness of sanctions & & & 0.72 & & -0.30 & \\
\hline Strictness of conditions & & & $9.04^{\star *}$ & & $7.19^{\star \star}$ & \\
\hline$R 2$ & 0.091 & & 0.142 & & 0.335 & \\
\hline RMSE & 0.504 & & 0.496 & & 0.448 & \\
\hline Observations & 390 & & 378 & & 368 & \\
\hline Countries & 16 & & 16 & & 16 & \\
\hline
\end{tabular}

All models include country fixed effects and panel-corrected standard errors with panel-specific autocorrelation. Abbreviation: RMSE, root mean square error.

$+p<0.1$.

${ }^{*} p<0.05$.

${ }^{* \star} p<0.01$.

${ }^{\star \star \star} p<0.001$.

As noted, partisan politics and 'demanding' activation may be correlated. One way of exploring this potential correlation is to introduce interaction terms between partisan politics and the two measures of conditionality. However, since the main effects must be evaluated together with the interaction term, it is useful to illustrate the interactions rather than interpreting coefficients directly, which is done by plotting marginal effects based on regression results (full results are available in the Appendix, Table A3). Since the relationship between partisan politics and activation is assumed to mainly be contingent on the level of activation, only the long-term marginal effects, based on variables expressed in levels, are shown. ${ }^{3}$

\footnotetext{
${ }^{3}$ It can be noted that the marginal effects related to the short-term interaction terms were not statistically significant for strictness of conditions and imprecise in relation to strictness of sanctions.
} 


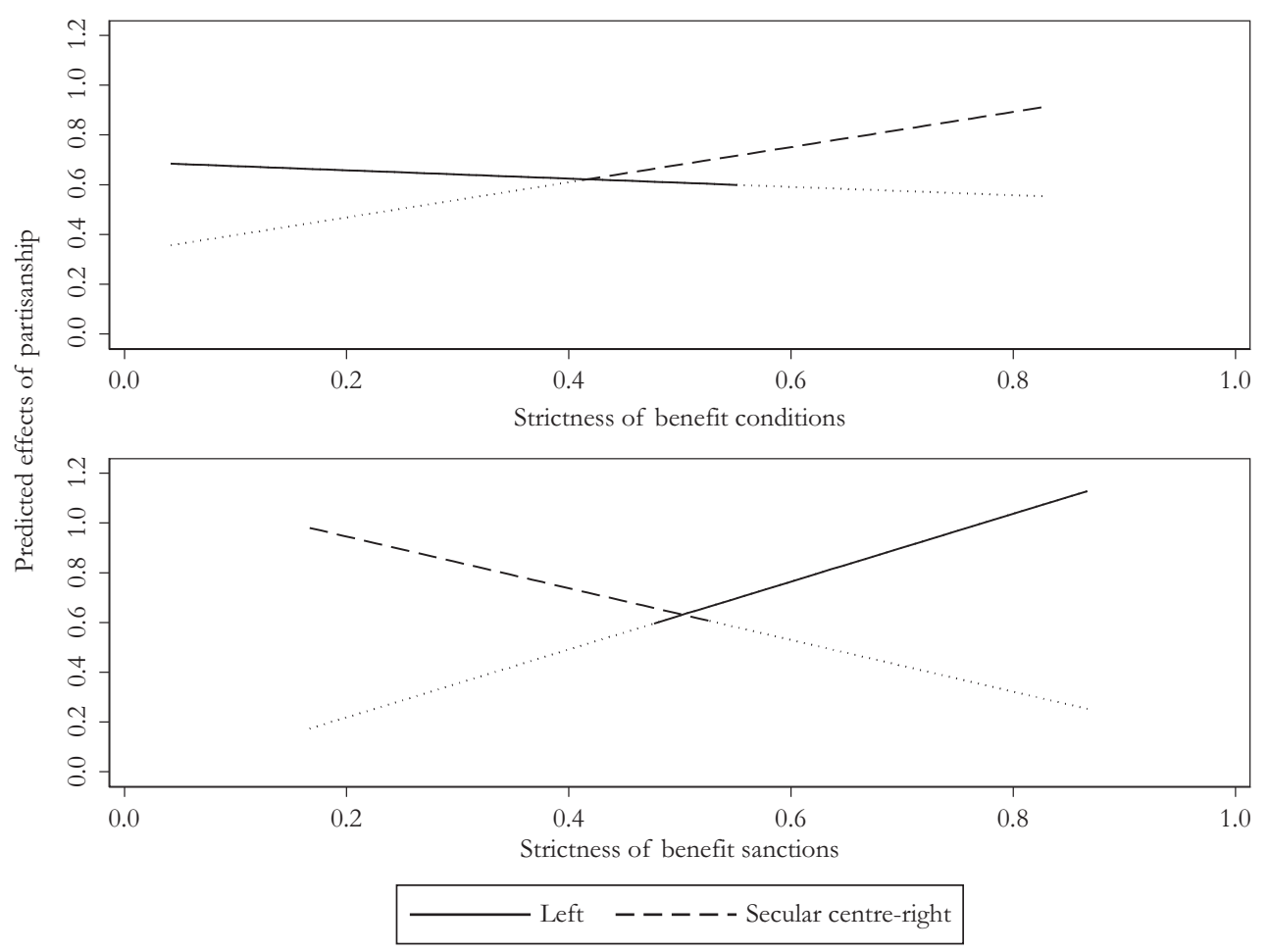

Figure 1. Average marginal effects of partisan politics. Note: The bold part of the lines indicates statistically significant marginal effects at the 95 per cent level.

Figure 1 shows marginal effects of partisanship at different values of the two measures of 'demanding' activation (based on the value range in the sample). The figure thus illustrates how effects of partisanship change in situations of higher or lower benefit conditionality. The results largely confirm the theoretical expectations. Left parties seem to spend less on PES as benefit conditions become stricter (statistically significant for low- to mid-level strictness of conditions). In contrast, the effects of left parties are strengthened and associated with more spending on PES as benefit sanctions become stricter (which holds for high levels of strictness). For secular-centre right parties, these effects are essentially reversed.

\section{Sensitivity analysis}

As noted above, there are various ways of measuring government spending. I have therefore estimated models where the dependent variable, PES spending, was defined as total spending on PES as a percentage of overall GDP. The results of this regression are available in Table A4 in the statistical appendix, restricted to show estimates related to partisan politics and strictness of conditions and sanctions. The signs of coefficients are mostly in the same direction as in the previous models with respect to partisan politics and benefit conditionality. However, the effects are not statistically significant at the 5 per cent level. It is likely that there is too little variation when considering PES spending as a percentage of GDP, which produces imprecise estimates. Additional sensitivity analysis included adding time fixed effects and jack-knife exclusion of countries. Including fixed effects for time and excluding one country at a time yielded similar, but less precise, estimates as shown in the main models.

\section{Conclusions}

This study set out to explore determinants of resources devoted to PES and asked whether partisan politics is related to PES once we consider the development of 'demanding' activation, and whether the 
development of activation in itself, as manifested in benefit conditionality, was related to PES spending. Beginning with the latter question, the results indicated that the strategy to use monitoring and sanctions to curb expenditures is not unequivocally successful. Increasing strictness of conditions, ie., restrictive access to benefits, was associated with increased total spending on PES. With that said, the costs related to monitoring must also be weighed against the reduced costs that increased conditionality could produce in relation to, eg., unemployment insurance. With respect to the role of political parties, the results indicated that partisan politics is a relevant determining factor for PES spending when controlling for changes in the strictness of two indicators of benefit conditionality. Although the increase in 'demanding' activation has been shown to be unrelated to partisan politics in other studies (Knotz, 2019), the fact that 'demanding' activation acts as a suppressor to partisan politics indicated that they are correlated, which was explored by examining the interplay between partisanship and benefit conditionality. While both left and secular centre-right parties were associated with increased spending on PES compared to confessional parties, the interplay with benefit conditionality had distinct patterns. Left parties were primarily associated with increased spending on PES in contexts where the strictness of benefit sanctions was high. This could be construed as a strategy to retain a generous insurance in terms of access, while still showing a willingness to emphasize the duties of the unemployed in order to avoid electoral backlash. Secular centre-right parties, on the other hand, were associated with increased spending when the access to benefits was stricter, which could reflect that support for the unemployed has traditionally not been a priority. Instead of sanctioning those already unemployed, secular centrist-right parties curb the right to benefits to create an incentive to avoid unemployment, while at the same time devoting resources to the PES to facilitate faster transitions from unemployment into work.

While this paper has argued that the role of partisan politics is relevant to consider in relation to PES, especially when we can account for the coercive elements of the PES, it should be noted that the current scholarly debate has raised criticism towards the 'traditional' left- versus right-wing perspective on partisan politics, instead emphasizing, eg., changing electorates and the role of context with respect to policy development (Häusermann, Picot, \& Geering, 2013). However, the reduced salience of class politics in terms of 'policy' reform may instead be evident when considering 'institutional' reform, where powerresources may be shifted to produce more long-term effects on redistribution that follow the traditional left-right scale (Elmelund-Præstekær \& Klitgaard, 2012; Klitgaard, Schumacher, \& Soentken, 2015). To some degree, the results of this study support this claim. The increase of 'demanding' activation seems to follow the logic of policy reform, where partisan politics is less salient, but changes in resources devoted to PES reflect institutional reform where partisan politics is still relevant to consider. However, there is still need to properly delineate political preferences towards various policies or interventions. The theoretical reasoning and results of this study suggests that it is important to not impose expectations from the 'traditional' partisan politics either. Whereas left parties are shown to conform to the assumption of expansive policies, PES is a type labour market policy palatable for centrist-right parties as well since PES spending can involve measures that are easily combined with a market logic and incentives. Confessional parties, on the other hand, have historically not been known to promote labour market policy that involve government intervention, thus following a different logic to that of social policy. Thus, preferences for welfare state policy is not just a reflection of left and right party preferences for expansion versus retrenchment, but can also be linked to other dimensions relevant for a particular type of policy, which needs to be addressed whenever the role of political actors is examined in welfare state development.

\section{References}

Bassanini, A., \& Duval, R. (2006). Employment Patterns in OECD Countries: Reassessing the Role of Policies and Institutions. Paris: OECD. (Social, Employment and Migration Working Papers).

Bassanini, A., \& Duval, R. (2009). Unemployment, institutions, and reform complementarities: Re-assessing the aggregate evidence for OECD countries. Oxford Review of Economic Policy, 25(1), 40-59.

Beck, N., \& Katz, J. N. (1995). What to do (and not to do) with time-series cross-section data. American Political Science Review, 89(3), 634-647. 
Bengtsson, M., de la Porte, C., \& Jacobsson, K. (2017). Labour market policy under conditions of permanent austerity: Any sign of social investment? Social Policy \& Administration, 51(2), 367-388.

Boeri, T., Conde-Ruiz, J. I., \& Galasso, V. (2012). The political economy of flexicurity. Journal of the European Economic Association, 10(4), 684-715.

Boix, C. (1998). Political Parties, Growth and Equality: Conservative and Social Democratic Economic Strategies in the World Economy. New York, NY: Cambridge University Press.

Bonoli, G. (2010). The political economy of active labor-market policy. Politics \& Society, 38(4), 435-457.

Bonoli, G. (2013). The Origins of Active Social Policy: Labour Market and Childcare Policies in a Comparative Perspective. Oxford: Oxford University Press.

Boone, J., Fredriksson, P., Holmlund, B., van Ours, J.C. (2007) Optimal unemployment insurance with monitoring and sanctions. The Economic Journal, 117, 399-421.

Bradley, D. H., \& Stephens, J. D. (2007). Employment performance in OECD countries - A test of neoliberal and institutionalist hypotheses. Comparative Political Studies, 40(12), 1486-1510.

Clasen, J., \& Clegg, D. (2003). Unemployment protection and labour market reform in France and Great Britain in the 1990s: Solidarity versus activation? Journal of Social Policy, 32(3), 361-381.

Clasen, J., \& Clegg, D. (2006). Beyond activation reforming european unemployment protection systems in post-industrial labour markets. European Societies, 8(4), 527-553.

Clasen, J., \& Clegg, D. (2007). Levels and levers of conditionality: Measuring change within welfare states. In J. Clasen, \& N. A. Siegel (Eds.), Investigating Welfare State Change: The 'Dependent' Variable Problem' in Comparative Analysis, Cheltenham: Edward Elgar Publishing.

Clasen, J., \& Clegg, D. (Eds.) (2011). Regulating the Risk of Unemployment: National Adaptations to Post-Industrial Labour Markets in Europe. Oxford: Oxford University Press.

Clasen, J., Clegg, D., \& Goerne, A. (2016). Comparative social policy analysis and active labour market policy: Putting quality before quantity. Journal of Social Policy, 45(01), 21-38.

Cronert, A. (2019). Unemployment reduction or labor force expansion? How partisanship matters for the design of active labor market policy in Europe. Socio-Economic Review, 17(4), 921-946.

De Boef, S., \& Keele, L. (2008). Taking time seriously. American Journal of Political Science, 52(1), 184-200.

Drukker, D. M. (2003). Testing for serial correlation in linear panel-data models. The Stata Journal, 3(2), $168-177$.

Eichhorst, W., \& Konle-Seidl, R. (2008). Does activation work? In W. Eichhorst, O. Kaufmann, \& R. Konle-Seidl (Eds.), Bringing the Jobless into Work? (pp. 415-444). Berlin, Heidelberg: Springer.

Elmelund-Præstekær, C., \& Klitgaard, M. B. (2012). Policy or institution? The political choice of retrenchment strategy. Journal of European Public Policy, 19(7), 1089-1107.

Esping-Andersen, G. (1996). Positive-sum solutions in a world of trade-offs? In G. Esping-Andersen (Ed.), Welfare States in Transition: National Adaptations in Global Economies (pp. 257-288). London: SAGE.

European Journal of Political Research (2014) Political data yearbook. European Journal of Political Research. Available from: http://www.politicaldatayearbook.com (accessed 18 March 2015).

Fossati, F. (2018a). How regimes shape preferences. A study of political actors' labour market policy preferences in flexicurity and dualizing countries. Socio-Economic Review, 16(3), 523-544.

Fossati, F. (2018b). Who wants demanding active labour market policies? Public attitudes towards policies that put pressure on the unemployed. Journal of Social Policy, 47(1), 77-97.

Freeman, R. B. (2005). Labour market institutions without blinders: The debate over flexibility and labour market performance. International Economic Journal, 19(2), 129-145.

Furåker, B. (1997). Arbetslinjen, socialbidrag och massarbetslöshet. In 11 Röster om Socialbidrag: En Antologi. Stockholm: Socialstyrelsen.

Garritzmann, J. L., \& Seng, K. (2020). Party effects on total and disaggregated welfare spending: A mixed-effects approach. European Journal of Political Research, 59(3), 624-645.

Häusermann, S., Picot, G., \& Geering, D. (2013). Review article: Rethinking party politics and the welfare state - Recent advances in the literature. British Journal of Political Science, 43(1), 221-240.

Hicks, A., \& Kenworthy, L. (1998). Cooperation and political economic performance in affluent democratic capitalism. American Journal of Sociology, 103(6), 1631-1672.

Huber, E., \& Stephens, J. D. (2001). Development and Crisis of the Welfare State: Parties and Policies in Global Markets. Chicago: University of Chicago Press.

Huber, E., \& Stephens, J. D. (2014). Income inequality and redistribution in post-industrial democracies: Demographic, economic and political determinants. Socio-Economic Review, 12(2), 245-267.

Huo, J., Nelson, M., \& Stephens, J. D. (2008). Decommodification and activation in social democratic policy: Resolving the paradox. Journal of European Social Policy, 18(1), 5-20.

Kalyvas, S. N., \& Van Kersbergen, K. (2010). Christian democracy. Annual Review of Political Science, 13(1), $183-209$.

Keele, L., Linn, S., \& Webb, C. M. (2016). Treating time with all due seriousness. Political Analysis, 24(1), 31-41. 
King, D. S., \& Rothstein, B. (1993). Institutional choices and labor market policy - A British-Swedish comparison. Comparative Political Studies, 26(2), 147-177.

Klitgaard, M. B., Schumacher, G., \& Soentken, M. (2015). The partisan politics of institutional welfare state reform. Journal of European Public Policy, 22(7), 948-966.

Knotz, C. (2018). A rising workfare state? Unemployment benefit conditionality in 21 OECD countries, 1980-2012. Journal of International and Comparative Social Policy, 34(2), 91-108.

Knotz, C. (2019). Why countries 'get tough on the work-shy': The role of adverse economic conditions. Journal of Social Policy, 48(03), 615-634.

Knotz, C., \& Nelson, M. (2018). The Comparative Conditions and Sanctions Dataset. Lund: Department of Political Science, Lund University.

Korpi, W., \& Palme, J. (2003). New politics and class politics in the context of austerity and globalization: Welfare state regress in 18 countries, 1975-95. American Political Science Review, 97(3), 425-446.

Lindvall, J. (2014). The electoral consequences of two great crises. European Journal of Political Research, 53(4), 747-765.

Lødemel, I. (2004). The development of workfare within social activation policies. In D. Gallie (Ed.), Resisting Marginalization (pp. 197-222). Oxford: Oxford University Press.

Montanari, I., \& Nelson, K. (2013). Health care determinants in comparative perspective: The role of partisan politics for health care provision. International Journal of Comparative Sociology, 54(5-6), 445-466.

Moreira, A., \& Lødemel, I. (2014). Governing activation in the 21st century. In I. Lødemel, \& A. Moreira (Eds.), Activation or Workfare? Governance and the Neo-Liberal Convergence (pp. 289-326). Oxford: Oxford University Press.

Mosley, H., Keller, T., \& Speckesser, S. (1998). The role of the social partners in the design and implementation of active measures. ILO Employment and Training Papers. Geneva: ILO.

Nelson, M. (2013). Making markets with active labor market policies: The influence of political parties, welfare state regimes, and economic change on spending on different types of policies. European Political Science Review, 5(2), $255-277$.

Nikolai, R. (2012). Towards social investment? Patterns of public policy in the OECD world. In N. Morel, B. Palier, \& J. Palme (Eds.), Towards a Social Investment Welfare State?: Ideas, Policies and Challenges (pp. 91-116). Chicago, IL: The Policy Press.

OECD/IDB/WAPES. (2016). The World of Public Employment Services. Washington, DC: Inter-American Development Bank.

OECD. (2015a). Main economic indicators (MEI).

OECD. (2015b). Social expenditure database (SOCX).

Powell, G. B., \& Whitten, G. D. (1993). A cross-national analysis of economic voting: Taking account of the political context. American Journal of Political Science, 37(2), 391-414.

Raffass, T. (2017). Demanding activation. Journal of Social Policy, 46(2), 349-365.

Rothstein, B. (1985). The success of the Swedish labor market policy - The organization connection to policy. European Journal of Political Research, 13(2), 153-165.

Rueda, D. (2006). Social democracy and active labour-market policies: Insiders, outsiders and the politics of employment promotion. British Journal of Political Science, 36, 385-406.

Rueda, D. (2007). Social Democracy Inside Out: Partisanship and Labor Market Policy in Industrialized Democracies. Oxford: Oxford University Press.

Rueda, D. (2015). The state of the welfare state: Unemployment, labor market policy, and inequality in the age of workfare. Comparative Politics, 47(3), 296-314.

Schumacher, G., Vis, B., \& Van Kersbergen, K. (2013). Political parties' welfare image, electoral punishment and welfare state retrenchment. Comparative European Politics, 11(1), 1-21.

Scruggs, L., \& Allan, J. P. (2004). Political partisanship and welfare state reform in advanced industrial societies. American Journal of Political Science, 48(3), 496-512.

Siegel, N. A. (2007). When (only) money matters: The pros and cons of expenditure analysis. In J. Clasen, \& N. A. Siegel (Eds), Investigating Welfare State Change: The 'Dependent' Variable Problem' in Comparative Analysis (pp. 43-71). Cheltenham: Edward Elgar Publishing.

Tepe, M., \& Vanhuysse, P. (2013). Parties, unions and activation strategies: The context-dependent politics of active labour market policy spending. Political Studies, 61(3), 480-504.

Thuy, P., Hansen, E., \& Price, D. (2001). The Public Employment Service in a Changing Labour Market. Geneva: International Labour Office.

Van Kersbergen, K. (1995). Social Capitalism: a Study of Christian Democracy and the Welfare State. London: Routledge.

Van Kersbergen, K. (2009). Religion and the Welfare State in the Netherlands. In K. Van Kersbergen, \& P. Manow (Eds), Religion, Class Coalitions, and Welfare States (pp. 119-145). Cambridge: Cambridge University Press.

Van Kersbergen, K., \& Hemerijck, A. (2009). Christian democracy, social democracy and the continental 'welfare without work' syndrom. In L. Bauld, N. Ellison, \& M. Powell (Eds.), Social Policy Review 16: Analysis and Debate in Social Policy, 2004 (p. 304). Bristol, UK: Policy Press.

Van Oorschot, W. (2000). Who should get what, and why? On deservingness criteria and the conditionality of solidarity among the public. Policy \& Politics, 28(1), 33-48. 
Van Oorschot, W. (2004). Balancing work and welfare: activation and flexicurity policies in The Netherlands, $1980-2000$. International Journal of Social Welfare, 13, 15-27.

Van Oorschot, W., \& Abrahamson, P. (2003). The Dutch and Danish miracles revisited: A critical discussion of activation policies in two small welfare states. Social Policy \& Administration 37(3), 288-304.

van Vliet, O., \& Koster, F. (2011). Europeanization and the political economy of active labour market policies. European Union Politics, 12(2), 217-239.

Visser, J. (2013). Database on institutional characteristics of trade unions, wage setting, state intervention and social pacts, 1960-2012 (ICTWSS). Amsterdam: University of Amsterdam.

Vlandas, T. (2013). Mixing apples with oranges? Partisanship and active labour market policies in Europe. Journal of European Social Policy, 23(1), 3-20.

Watts, B., \& Fitzpatrick, S. (2018). Welfare Conditionality. New York: Routledge.

Weishaupt, J. T. (2010). A silent revolution? New management ideas and the reinvention of European public employment services. Socio-Economic Review, 8(3), 461-486.

Weishaupt, J. T. (2011). From the Manpower Revolution to the Activation Paradigm - Explaining Institutional Continuity and Change in an Integrating Europe. Amsterdam: Amsterdam University Press.

\section{A. APPENDIX}

Table A1. Average lags for independent variables.

\begin{tabular}{lc}
\hline Variable & Average lag \\
\hline Left cabinet share & 1.47 \\
\hline Secular centre-right cabinet share & 1.47 \\
\hline Strictness of conditions & 1.20 \\
\hline Strictness of sanctions & 1.07 \\
\hline Civilian unemployment rate & 2.00 \\
\hline Deindustralization & 1.24 \\
\hline Wage coordination & 1.25 \\
\hline Adjusted deficit & 1.59 \\
\hline GDP per capita & 1.44 \\
\hline Employment protection & 1.13 \\
\hline
\end{tabular}

Obtained through estimation of ADL without covariates, where lags are chosen according to lowest BIC. 
Table A2. Fisher panel unit-root tests (augmented Dickey-Fuller regressions).

\begin{tabular}{|c|c|c|c|c|}
\hline Variable & Inverse chi-squared & Inverse normal & Inverse logit & Mod inv. chi-squared \\
\hline PES & 0.75 & 0.77 & 0.77 & 0.76 \\
\hline Left cabinet share & 0.00 & 0.00 & 0.00 & 0.00 \\
\hline Centre-right cabinet share & 0.00 & 0.00 & 0.00 & 0.00 \\
\hline Strictness of conditions ${ }^{*}$ & 0.00 & 0.00 & 0.00 & 0.00 \\
\hline Strictness of sanctions ${ }^{*}$ & 0.00 & 0.00 & 0.00 & 0.00 \\
\hline Civilian unemployment rate & 0.00 & 0.00 & 0.00 & 0.00 \\
\hline Deindustralization (8) & 0.00 & 0.68 & 0.21 & 0.00 \\
\hline Wage coordination & 0.00 & 0.00 & 0.00 & 0.00 \\
\hline GDP per capita* & 0.00 & 0.00 & 0.00 & 0.00 \\
\hline Adjusted deficit & 0.02 & 0.01 & 0.02 & 0.01 \\
\hline Employment protection ${ }^{*}$ & 0.00 & 0.00 & 0.00 & 0.00 \\
\hline$\triangle \mathrm{PES}$ & 0.00 & 0.00 & 0.00 & 0.00 \\
\hline$\Delta$ Left cabinet share & 0.00 & 0.00 & 0.00 & 0.00 \\
\hline$\Delta$ Centre-right cabinet share & 0.00 & 0.00 & 0.00 & 0.00 \\
\hline$\Delta$ Strictness of conditions & 0.00 & 0.00 & 0.00 & 0.00 \\
\hline$\Delta$ Strictness of sanctions & 0.00 & 0.00 & 0.00 & 0.00 \\
\hline$\Delta$ Civilian unemployment rate & 0.00 & 0.00 & 0.00 & 0.00 \\
\hline$\Delta$ Deindustralization & 0.00 & 0.00 & 0.00 & 0.00 \\
\hline$\Delta$ Wage coordination & 0.00 & 0.00 & 0.00 & 0.00 \\
\hline$\Delta$ GDP per capita & 0.00 & 0.00 & 0.00 & 0.00 \\
\hline$\Delta$ Adjusted deficit & 0.00 & 0.00 & 0.00 & 0.00 \\
\hline$\Delta$ Employment protection & 0.00 & 0.00 & 0.00 & 0.00 \\
\hline
\end{tabular}

$\mathrm{H} 0$ - All panels contain unit roots. $\mathrm{H} 1$ - At least one panel is stationary. A p value below 0.05 entails rejection of null. Additional lags included in ADF regressions in parentheses. "Indicates inclusion of drift term. Deindustralization is detrended, as the Fisher test indicates a time trend. For other variables, including a time trend yields similar results as shown.

Abbreviation: PES, public employment services.

Table A3. Interaction models.

\begin{tabular}{|c|c|c|c|c|c|c|c|c|}
\hline & \multicolumn{2}{|c|}{ Model 1} & \multicolumn{2}{|c|}{ Model 2} & \multicolumn{2}{|c|}{ Model 3} & \multicolumn{2}{|c|}{ Model 4} \\
\hline & Change & Lag & Change & Lag & Change & Lag & Change & Lag \\
\hline PES & & $-0.25^{\star \star *}$ & & $-0.23^{\star \star *}$ & & $-0.24^{\star \star *}$ & & $-0.24^{\star \star \star}$ \\
\hline Left cabinet share & 0.08 & -0.24 & $0.78^{*}$ & $0.81^{\star}$ & 0.53 & $0.66^{*}$ & $0.59^{\star}$ & $0.70^{\star}$ \\
\hline $\begin{array}{l}\text { Secular-centre } \\
\text { cabinet sh. }\end{array}$ & $0.63^{*}$ & $0.64^{*}$ & $0.68^{*}$ & $0.63^{*}$ & $0.87^{\star}$ & $1.27^{\star \star \star}$ & 0.35 & 0.17 \\
\hline $\begin{array}{l}\text { Strictness of } \\
\text { sanctions }\end{array}$ & -0.06 & -0.55 & 0.06 & -0.13 & 0.41 & 0.64 & -0.02 & -0.33 \\
\hline
\end{tabular}


Table A3. Continued

\begin{tabular}{|c|c|c|c|c|c|c|c|c|}
\hline & \multicolumn{2}{|c|}{ Model 1} & \multicolumn{2}{|c|}{ Model 2} & \multicolumn{2}{|c|}{ Model 3} & \multicolumn{2}{|c|}{ Model 4} \\
\hline & Change & Lag & Change & Lag & Change & Lag & Change & Lag \\
\hline $\begin{array}{l}\text { Strictness of } \\
\text { conditions }\end{array}$ & 0.86 & $1.90^{\star *}$ & 0.76 & $1.73^{*}$ & 0.77 & $1.84^{\star *}$ & 0.40 & 1.11 \\
\hline \multicolumn{9}{|l|}{ Interactions } \\
\hline Left* sanctions & 0.82 & $1.77^{\star}$ & & & & & & \\
\hline Left ${ }^{\star}$ conditions & & & -0.45 & -0.39 & & & & \\
\hline $\begin{array}{l}\text { Secular }{ }^{*} \\
\text { sanctions }\end{array}$ & & & & & -0.43 & -1.25 & & \\
\hline $\begin{array}{l}\text { Secular* } \\
\text { conditions }\end{array}$ & & & & & & & 0.70 & 1.01 \\
\hline Constant & & & & & & & & \\
\hline \multicolumn{9}{|c|}{ Long-term effects (LRM) } \\
\hline Left & & & & & & & & \\
\hline Left $^{\star}$ sanctions & & & & & & & & \\
\hline Left $^{*}$ conditions & & & & & & & & \\
\hline $\begin{array}{l}\text { Secular centre- } \\
\text { right }\end{array}$ & & & & & \multicolumn{2}{|c|}{$5.27^{\star *}$} & \multicolumn{2}{|c|}{0.68} \\
\hline $\begin{array}{l}\text { Secular* } \\
\text { sanctions }\end{array}$ & & & \multicolumn{6}{|c|}{-5.16} \\
\hline $\begin{array}{l}\text { Secular* } \\
\text { conditions }\end{array}$ & & & & & & & \multicolumn{2}{|c|}{$4.15^{\star}$} \\
\hline$R 2$ & \multicolumn{2}{|c|}{0.346} & \multicolumn{2}{|c|}{0.337} & \multicolumn{2}{|c|}{0.341} & \multicolumn{2}{|c|}{0.342} \\
\hline RMSE & \multicolumn{2}{|c|}{0.45} & \multicolumn{2}{|c|}{0.45} & \multicolumn{2}{|c|}{0.45} & \multicolumn{2}{|c|}{0.45} \\
\hline Observations & \multicolumn{2}{|c|}{368} & \multicolumn{2}{|c|}{368} & \multicolumn{2}{|c|}{368} & \multicolumn{2}{|c|}{368} \\
\hline Countries & \multicolumn{2}{|c|}{16} & \multicolumn{2}{|c|}{16} & \multicolumn{2}{|c|}{16} & \multicolumn{2}{|c|}{16} \\
\hline
\end{tabular}

All models include all macro-level control variables.

Abbreviations: PES, public employment services; RMSE, root mean square error.

${ }^{*} p<0.05$.

${ }^{* *} p<0.01$.

${ }^{\star * \star} p<0.001$. 
Table A4. Robustness check. PES spending as percent of GDP.

\begin{tabular}{|c|c|c|}
\hline & Change & Lag \\
\hline PES (as percent of GDP) & & -0.07 \\
\hline Left cabinet share & -0.00 & 0.01 \\
\hline Secular-centre cabinet share & 0.00 & 0.01 \\
\hline Strictness of sanctions & -0.02 & -0.02 \\
\hline Strictness of conditions & -0.03 & $0.07^{\star}$ \\
\hline Unemployment & 0.00 & 0.00 \\
\hline Deindustrialization & 0.63 & 0.16 \\
\hline Wage coordination & 0.00 & $0.01^{*}$ \\
\hline GDP per capita & -0.10 & -0.01 \\
\hline Adjusted deficit & -0.00 & 0.00 \\
\hline Employment protection & -0.01 & 0.01 \\
\hline Constant & -0.06 & \\
\hline \multicolumn{3}{|l|}{ Long-term effects (LRM) } \\
\hline Left cabinet share & 0.09 & \\
\hline Secular-center cabinet share & 0.09 & \\
\hline Strictness of sanctions & -0.27 & \\
\hline Strictness of conditions & 0.99 & \\
\hline$R 2$ & 0.230 & \\
\hline RMSE & 0.03 & \\
\hline Observations & 368 & \\
\hline Countries & 16 & \\
\hline
\end{tabular}

Includes country-fixed effects, panel-corrected standard errors and panel-specific autocorrelation.

Abbreviations: PES, public employment services; RMSE, root mean square error.

${ }^{*} p<0.05$.

Cite this article: Fredriksson, D. (2021). Determinants of public employment services: exploring the relationship between benefit conditionality and partisan politics. Journal of International and Comparative Social Policy 37: 142-158. https://doi. $\operatorname{org} / 10.1017 /$ ics.2020.34 